\title{
No evidence of Human Cytomegalovirus infection among Behcet's Patients
}

\author{
Saied Ghorbani ${ }^{1,2}$, Davod Javanmard ${ }^{1,3}$, Seyed Jalal Kiani ${ }^{1}$, Ahmad Tavakoli $^{1}$, Somayeh Sadat Moochani ${ }^{1}$, \\ Seyed Hamid Reza Monavari ${ }^{{ }^{*}}$
}

1. Department of Virology, School of Medicine, Iran University of Medical Sciences, Tehran, Iran

2. Student Research Committee, Iran University of Medical Sciences, Tehran, Iran

3. Infectious Diseases Research Center, Birjand University of Medical Sciences, Birjand, Iran

\subsection{9/ijmm.14.2.133}

\section{ABSTRACT}

Background: Behcet's Disease (BD) is one of the chronic inflammatory diseases with unknown etiology. The relationship between infectious agents and BD has not been clearly identified yet. Human cytomegalovirus (HCMV) causes a primary infection in the first years of life and remains latent in various tissues and cells. This study aimed to find out the frequency of HCMV among BD patients.

Methods: In this cross-sectional study, serum samples from 103 BD patients were analyzed for HCMV by molecular and serological tests. The results were analyzed by IBM SPSS version 20.

Results: The mean age of BD patients was $38.67 \pm 8.82$, and $53 \%(54 / 103)$ were male. The mean duration of BD was $18.42 \pm 6.12$ years. HCMV IgG antibody was found in $96 \%$ and $94 \%$ of males and females, respectively, and the IgM antibody was positive only in one male patient. HCMV DNA was not detected in the samples.

Conclusion: Our result showed, there is no evidence of Cytomegalovirus infection among Behcet's patients. Like other studies IgG antibodies against CMV are prominent among the general population.and Behcet patients. While, IgM against HCMV was positive only in one patients. But, no CMV-DNA detected among 103 Behcet patients. However, the absence of the virus genome in a positive IgM person can be due to the Short-term DNAemia or due to rheumatoid factor interference. In addition, there is a time lag between primary infection and IgM antibody production (IgM level can remain undetectable because of delayed seroconversion owing to immunosuppressive agents). IgM antibodies can also persist for a long time after infection in some healthy individuals.

Keywords: Behcet's Syndrome, Cytomegalovirus, Virus Latency

Received: 2020/01/03; Accepted: 2020/03/10; Published Online: 2020/04/25

\begin{tabular}{|c|c|}
\hline Corresponding Information: & $\begin{array}{l}\text { Seyed Hamid Reza Monavari, Department of Virology, School of Medicine, Iran University of Medical Sciences, Tehran, Iran. } \\
\text { Email: hrmonavari@yahoo.com }\end{array}$ \\
\hline (c) (1) (5) & $\begin{array}{l}\text { This is an original open-access article distributed under the terms of the Creative Commons Attribution-noncommercial } 4.0 \text { International License which } \\
\text { edistribution of the material just in noncommercial usages with proper citation. }\end{array}$ \\
\hline
\end{tabular}

Use your device to scan and read the article online

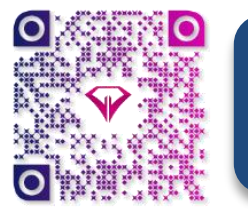

Ghorbani S, Javanmard D, Kiani S J, Tavakoli A, Moochani S S, Monavari S H R. No evidence of Human

Cytomegalovirus infection among Behcet's Patients. Iran J Med Microbiol. 2020; 14 (2):133-137

\section{Download citation: BibTeX | RIS | EndNote | Medlars | ProCite | Reference Manager | RefWorks}
Send citation to:
Mendeley
(2) Zotero
(1) RefWorks

\section{Introduction}

Behcet's disease (BD) was first introduced in 1937 by Hulusi Behçet (1). BD is a chronic and systemic vasculitis with inflammation and dysfunction of various organs and systems including: immune system, central nerve system, heart, gastrointestinal tract and joints. The disease is characterized by the occurrence of recurrent aphthous ulcer in different parts of the body. According to several studies, outbreaks of BD are most commonly reported from Turkey, with a prevalence of 20-421 cases per 100000 population. After Turkey, Iran is the second most prevalent country with about $80 / 100000$, in general 
population. The prevalence of BS in the Middle East, varies between 17-80/100000, and in the Far East, the prevalence of BS is approximately 2.6-15/100000 among Japanese and Chinese people. On the other hand, the prevalence of BD in western and European countries, e.g. the United Kingdom and the United States is ranged from $0.12-0.66$ per 100000 in General population (2-5). The etiology and pathogenesis of Behcet disease are not clear but are assumed to be multifactorial, including the involvement of genetics (human leukocyte antigen (HLA-B51 allele)), infectious agents (bacteria and viruses), and immunological factors (2).

Herpesviridae is a large family of DNA viruses that cause infections in animals and humans. Distinct viruses of the family are associated with several important diseases in humans including Herpes Simplex Virus 1 and 2 (HSV-1,2), Epstein-Barr Virus (EBV), Human Herpes Virus 6 and 7 (HHV-6,7), Kaposi's sarcoma-associated herpesvirus (HHV-8), and Human cytomegalovirus(HCMV) $(6,7)$. HCMV belongs to betaherpesvirinae subfamily and cytomegalovirus genus (8). The virus often causes asymptomatic primary infection in the first years of life and remains latent in monocytes, bone marrow, and other tissues $(9,10)$. However, several studies have been conducted about the prevalence of HCMV in the Behcet's, but, Concurrent prevalence of IgG, IgM antibodies against HCMV and virus DNA titers in serum of Behcet's patients has not been studied.

\section{Materials and Methods}

\section{Study Population}

This was a cross-sectional study including 103 Behcet's patients ( 54 male and 49 female). They were referred to hospitals affiliated with Iran University of Medical Sciences in the period between January 2016 and February 2019. Ethical approval for this study was obtained from IUMS's Medical Ethics Committee (Ethic code number: IR.IUMS.REC 1396.32331). Written informed consent was obtained from all the study patients.

\section{Collection and Preparation of the Samples}

About $10 \mathrm{~mL}$ of whole blood samples was collected from each patient. Serum was separated by centrifugation and stored at $-80^{\circ} \mathrm{C}$ and $-20^{\circ} \mathrm{C}$ for HCMV DNA and serological examinations, respectively.

\section{Serological assays}

HCMV serological markers including $\lg M$ and $\lg G$ were tested by a Vircell ELISA kit according to the manufacturer's instructions (Vircell, Spain).

\section{DNA extraction and Polymerase Chain Reaction}

HCMV DNA was extracted from $220 \mu$ of the serum using a High Pure Viral Nucleic Acid Kit (Roche Diagnostics $\mathrm{GmbH}$, Mannheim, Germany) with a procedure adapted from the manufacturer's recommendation. DNA was eluted using $30 \mu \mathrm{l}$ of the RNAase/DNAase free buffer and stored in $-70{ }^{\circ} \mathrm{C}$. For HCMV DNA detection in the serum samples, Real time PCR was performed using TaqMan kit, based to the manufacturer's instructions. A highly conserved region of the glycoprotein $B$ (UL55) gene was selected for amplification of HCMV DNA. Sequences of the HCMV primers and probe was as follows (11):

HCMV Forward Primer (5'-TGGGCGAGGACAACGAA -3')

HCMV Reverse Primer (5' - TGAGGCTGGGAAGCTGACAT-3')

\section{HCMV PROBE (5'-6-FAM-TCGGCAACCACCGCACTG-BHQ-3').}

Real-time PCR was performed by TaqMan universal master mix. DNA was added to a $16 \mu \mathrm{L}$ PCR mixture containing $8 \mu \mathrm{L}$ of TaqMan universal PCR master mix, $1 \mu \mathrm{L}$ each primer and probe mix. The reaction consisted of 10 minutes at $94^{\circ} \mathrm{C}$, followed by 40 cycles of amplification, including $15 \mathrm{~s}$ at $94^{\circ} \mathrm{C}$ and $40 \mathrm{~s}$ at $60^{\circ} \mathrm{C}$.

\section{Statistical analysis}

Statistical analysis was done using IBM SPSS version 20 (IBM Corp., Armonk, NY, USA). Data was reported as mean \pm standard deviation. For all comparisons, $\mathrm{p}$ values $<0.05$ were considered to be statistically significant.

\section{Results}

Of 103 participated patients, 53\% (54/103) were male and $47 \%$ (49/103) were female. The mean age was $38.86 \pm 8.76$ and $39.35 \pm 7.50$ in males and females, respectively, which had not significant difference between male and female (Table 1). Also, the duration of disease was $20.34 \pm 5.87$ and $18.82 \pm 5.96$ in males and females, respectively. HCMV IgG antibody was found in $96 \%$ and $94 \%$ of males and females, respectively, and IgM antibody was positive only in one male patient. Our Real time PCR assay detected no HCMV DNA in the study patients. Despite the high prevalence of IgG antibody against cytomegalovirus in Behcet's patients, no virus genome was found in these patients (table1). 
Table 1. Demographic parameters as well as laboratory data for the studied Behcet patients

\begin{tabular}{|c|c|c|c|}
\hline \multirow{2}{*}{ Parameters } & \multicolumn{2}{|c|}{$\operatorname{Sex}(n=103)$} & \multirow{2}{*}{ P-value or Odds ratio $\left(\mathrm{CI}_{95 \%}\right)$} \\
\hline & Male (54) & Female (49) & \\
\hline Age, mean \pm SD & $38.86 \pm 8.76$ & $39.35 \pm 7.50$ & 0.89 \\
\hline HCMV-IgM & (1) $1.8 \%$ & 0 & 0.77 \\
\hline HCMV-IgG & (52) $96 \%$ & (46) $94 \%$ & 0.95 \\
\hline HCMV-DNA & 0 & 0 & 0.999 \\
\hline Duration (month) & $20.34 \pm 5.87$ & $18.82 \pm 5.96$ & 0.81 \\
\hline Treatment recipients & $100 \%$ & $100 \%$ & 0.999 \\
\hline
\end{tabular}

Standard deviation (SD)

\section{Discussion}

The exact role of infectious agents, especially viruses, in the pathogenesis of rheumatic diseases is unclear (12). In people with inflammatory diseases, individuals receiving immunosuppressive therapy and with a genetic predisposition, infection with environmental factors such as viruses can lead to immune system disruption (13-16). In this study, we investigated the levels of IgG and IgM antibodies against HCMV as well as the DNA of the HCMV virus in the serum of patients with Behcet's syndrome. Our results showed that the prevalence of IgG antibody against HCMV was $96 \%$ and $94 \%$ in male and female respectively. However, IgM was positive in one male patient and no DNA virus was detected in the patients. IgG antibodies against CMV are seen in $95 \%$ of the general population. However, the absence of the virus genome in a positive IgM person can be due to the Short-term DNAemia. the study by Sulieman showed among 17 patients with positive IgM against CMV, 10 cases have PCR positive, while among 7 cases the CMV-DNA not founded (17).

HCMV causes primary infection in the first years of life and remains mainly latent in monocytes, bone marrow, and other tissues $(9,18)$. On the other hand, Due to the impaired immune system and the abundant use of immunosuppressive or antimetabolite treatment in Behcet's patients, they are susceptible to viral infection $(13,19)$. HCMV with transmission to endothelium or fibroblasts cells can negatively affect the prognosis of patients with immune deficiency (20).

Oner et al., Showed that IgG titers against HCMV were positive in $100 \%$ of Behcet's patients, but antibody titers were lower than controls (19). Sari's study showed that HCMV colitis develops in Behcet's patients with neurological involvement following TNF inhibitor use (21). Other studies have also shown that use of immunosuppressive drugs in gastrointestinal patients with Behcet's disease due to HCMV virus causes gastrointestinal lesions, but with treatment discontinuation, these lesions return (22). The study by Lee et al. showed that HCMV plays a role in the return of ulcers in Behcet's patients (23). Similar to the Oner study, Seoudi's study also showed that IgG antibody titers were lower in Behcet's patients compared to controls (24). In the present study, unlike previous studies, there was no control group. But IgM antibody and virus genome levels were assessed. IgG positivity and lack of virus genome in the serum may be due to the virus being in the latent stage or the virus being cleared from the body. The results of this study indicated that no infectious HCMV can be detected in serum samples of Behcet's patients by our TaqMan realtime PCR assay. There are some limitations to the explanation of the test results for IgM. The disadvantage, false-positive results due to rheumatoid factor interference. and in immunosuppressed patients, e.g. chronic renal failure, end-stage renal disease and blood diseases (25). In addition, there is a time lag between primary infection and IgM antibody production (IgM level can remain undetectable because of delayed seroconversion owing to immunosuppressive agents). IgM antibodies can also persist for a long time after infection in some healthy individuals (26).

Limitation: The lack of a control group is the most important limitation of this study

\section{Acknowledgment}

This project was financially supported by a grant from the Iran University of Medical Sciences (No: IR.IUMS.REC 1396.32331).

\section{Conflict of Interest}

Authors declared no conflict of interests.

\section{References}

1. Khairallah M, Accorinti M, Muccioli C, Kahloun R, Kempen JH. Epidemiology of behçet disease. Ocular immunology and inflammation 2012;20:324-35. [DOI:10.3109/09273948.2012.723112] [PMID] 
2. Dalvi SR, Yildirim R, Yazici Y. Behcet's syndrome. Drugs 2012;72:2223-41. [DOI:10.2165/11641370000000000-00000] [PMID]

3. Ramezani MA. Prevalence of clinical manifestations of behcet's disease in kerman from 1996 to 2004. J Med Sci 2004;4:120-3. [DOI:10.3923/jms.2004.120.123]

4. Farajzadeh S, Shakibi M, Moghaddam SD, Rahnama Z. Behcet disease: Clinical spectrum and association with hepatitis $b$ and c viruses. 2005.

5. Davatchi F, Shahram F, CHAMS-DAVATCHI C, Shams $H$, Nadji $A$, Akhlaghi $M$, et al. Behcet's disease in iran: Analysis of 6500 cases. International journal of rheumatic diseases 2010;13:367-73. [DOI:10.1111/i.1756-185X.2010.01549.x] [PMID]

6. Tavakoli A, Monavari SH, Bokharaei-Salim F, Mollaei $\mathrm{H}$, Abedi-Kiasari B, Fallah $\mathrm{FH}$, et al. Asymptomatic herpes simplex virus infection in iranian mothers and their newborns. Fetal and pediatric pathology 2017;36:27-32.

[DOI:10.1080/15513815.2016.1229368] [PMID]

7. Sharma V, Mobeen F, Prakash T. Comparative genomics of herpesviridae family to look for potential signatures of human infecting strains. International journal of genomics 2016;2016. [DOI:10.1155/2016/9543274] [PMID] [PMCID]

8. Davison AJ. Herpesvirus systematics. Veterinary microbiology 2010;143:52-69. [DOI:10.1016/j.vetmic.2010.02.014] [PMID] [PMCID]

9. Scheinberg P, Fischer SH, Li L, Nunez O, Wu CO, Sloand EM, et al. Distinct ebv and cmv reactivation patterns following antibody-based immunosuppressive regimens in patients with severe aplastic anemia. Blood 2007;109:3219-24. [DOI:10.1182/blood-2006-09-045625] [PMID] [PMCID]

10. Hummel M, Abecassis MM. A model for reactivation of $\mathrm{cmv}$ from latency. Journal of Clinical Virology 2002;25:123-36. 6532(02)00088-4]

[DOI:10.1016/S1386-

11. Meshesha MK, Bentwich Z, Solomon SA, Avni YS. In vivo expression of human cytomegalovirus (hcmv) micrornas during latency. Gene 2016;575:101-7. [DOI:10.1016/i.gene.2015.08.040] [PMID]

12. Perl A. Mechanisms of viral pathogenesis in rheumatic disease. Annals of the rheumatic diseases 1999;58:454-61. [DOI:10.1136/ard.58.8.454] [PMID] [PMCID]

13. Halenius A, Hengel $H$. Human cytomegalovirus and autoimmune disease. BioMed research international 2014;2014. [DOI:10.1155/2014/472978] [PMID]
14. Landais I, Nelson JA. Functional genomics approaches to understand cytomegalovirus replication, latency and pathogenesis. Current opinion in virology 2013;3:408-15. [DOI:10.1016/j.coviro.2013.06.002] [PMID] [PMCID]

15. Cooke S, Rigby S, Griffiths D, Venables P, editors. Viral studies in rheumatic disease. Annales de medecine interne; 1998.

16. Schoenfisch AL, Dollard SC, Amin M, Gardner LI, Klein $\mathrm{RS}$, Mayer $\mathrm{K}$, et al. Cytomegalovirus (cmv) shedding is highly correlated with markers of immunosuppression in cmv-seropositive women. Journal of medical microbiology 2011;60:768-74. [DOI:10.1099/jmm.0.027771-0] [PMID]

17. El Sanousi SM, Osman ZA, Mohamed A, Al Awfi MS, Babair YH, Babair MH. Comparison of real-time pcr versus elisa in the diagnosis of cytomegalovirus infection in pregnant women. Clin Microbiol Infect Dis 2016;1:67-9. [DOI:10.15761/CMID.1000114]

18. Leng SX, Kamil J, Purdy JG, Lemmermann NA, Reddehase MJ, Goodrum FD. Recent advances in cmv tropism, latency, and diagnosis during aging. Geroscience 2017;39:251-9. [DOI:10.1007/s11357017-9985-7] [PMID] [PMCID]

19. Oner R, Sayiner S, Akgun S. Cytomegalovirus antibody titers in patients with behcet's disease. Intern Med 2018;8:2.

20. Sinzger C, Grefte A, Plachter B, Gouw AS, Jahn G. Fibroblasts, epithelial cells, endothelial cells and smooth muscle cells are major targets of human cytomegalovirus infection in lung and gastrointestinal tissues. Journal of General Virology 1995;76:741-50. [DOI:10.1099/0022-1317-76-4-741] [PMID]

21. Sari I, Birlik M, Gonen C, Akar S, Gurel D, Onen F, et al. Cytomegalovirus colitis in a patient with behcet's disease receiving tumor necrosis factor alpha inhibitory treatment. World Journal of Gastroenterology: WJG 2008;14:2912. [DOI:10.3748/wig.14.2912] [PMID] [PMCID]

22. Mikami S, Nakase H, Ueno S, Matsuura M, Sakurai T, Chiba T. Involvement of cytomegalovirus infection in the ileal lesions of the patient with behçet's disease. Inflammatory bowel diseases 2007;13:802-3. [DOI:10.1002/ibd.20105] [PMID]

23. Lee EB, Kwon YJ, Shin KC, Song YW, Park C-G, Hwang $E-S$, et al. Decreased serum level of antibody against human cytomegalovirus in patients with behcet's disease. Rheumatology international 2005;25:33-6. [DOI:10.1007/s00296-003-0394-0] [PMID]

24. Seoudi N, Bergmeier LA, Hagi-Pavli E, Bibby D, Fortune $\mathrm{F}$. The seroprevalence and salivary shedding of herpesviruses in behcet's syndrome and recurrent 
aphthous stomatitis. Journal of oral microbiology 2015;7:27156. [DOI:10.3402/jom.v7.27156] [PMID]

25. Lazzarotto T, Spezzacatena P, Varani S, Gabrielli L, Pradelli P, Guerra B, et al. Anticytomegalovirus (anti$\mathrm{cmv}$ ) immunoglobulin $\mathrm{g}$ avidity in identification of pregnant women at risk of transmitting congenital cmv infection. Clin Diagn Lab Immunol 1999;6:127-9. [DOI:10.1128/CDLI.6.1.127-129.1999] [PMID]

26. Lazzarotto T. The best practices for screening, monitoring, and diagnosis of cytomegalovirus disease, part ii. Clinical Microbiology Newsletter 2010;32:9-15.

[DOI:10.1016/i.clinmicnews.2009.12.004] 